Journal of Medical and Health Studies (JMHS)

ISSN: 2710-1452

DOI: 10.32996/jmhs

Journal Homepage: www.al-kindipublisher.com/index.php/jmhs

\title{
Correlation Between Duration of Hemodialysis and Depression in Chronic Kidney Disease
}

\author{
Caesariska Deswima ${ }^{1}$, Widodo $^{2}$ and Erikavitri Yulianti ${ }^{3} \square$ \\ ${ }^{1}$ Faculty of Medicine, Universitas Airlangga, Surabaya, Indonesia \\ ${ }^{2}$ Department of Internal Medicine, Faculty of Medicine, Universitas Airlangga - Dr. Soetomo General Academic Hospital, \\ Surabaya, Indonesia \\ ${ }^{3}$ Department of Psychiatry, Faculty of Medicine, Universitas Airlangga - Dr. Soetomo General Academic Hospital, Surabaya, \\ Indonesia
}

$\square$ Corresponding Author: Erikavitri Yulianti, E-mail: rikahus@yahoo.co.id

\begin{tabular}{ll}
\hline ARTICLE INFORMATION & ABSTRACT \\
\hline
\end{tabular}

Received: 01 November 2021

Accepted: 25 November 2021

Published: 31 December 2021

DOI: $10.32996 / j m h s .2021 .2 .2 .17$

\section{KEYWORDS}

Chronic Kidney Disease,

Hemodialysis, Depression,

Duration of Hemodialysis, Beck

Depression Inventory
Depression is commonly found in stage 5 CKD patients. However, depression in HD patients is usually neglected, underdiagnosed, and remains untreated. Duration of HD is reported to be significantly correlated with depression. Previously, there were several similar studies with varying results. This study is needed to detect depression and give early intervention to reduce hospitalization rates and patient mortality. This study aims to find the correlation between the duration of hemodialysis and depression in CKD patients. A cross-sectional was carried out on 52 patients with CKD undergoing HD in Dr. Soetomo General Academic Hospital using consecutive sampling. Beck Depression Inventory-II (BDI-II) questionnaire was used to measure the depression score. Data were analyzed with the Pearson correlation test. This study showed a significant negative correlation between the duration of hemodialysis and depression ( $p=0.005$, $p>0,05 ; r=-0.094)$. Duration of hemodialysis was significantly correlated with depression. The longer duration of hemodialysis, the lower score of depression. Periodic evaluation of HD patients for depression is needed for early intervention to reduce morbidity.

\section{Introduction}

Chronic kidney disease (CKD) is defined as kidney damage and/or glomerular filtration rate (GFR) less than $60 \mathrm{~mL} / \mathrm{min} / 1.73 \mathrm{~m}{ }^{2}$ of for at least three months which is classified into five stages (National Kidney Foundation, 2002). Globally, the estimated overall prevalence of CKD was $13.4 \%$ and stages 3-5 was 10.6\% (Hill, 2006). According to the National Basic Health Research 2018 Report, the prevalence of CKD in Indonesia is $0.38 \%$ or 713.783 people (Indonesian Renal Registry, 2018). Patients with CKD stage 5 require renal function replacement therapy, which consists of hemodialysis (HD), Continuous Ambulatory Peritoneal Dialysis (CAPD), and kidney transplantation to prolong and maintain optimal quality of life (Departemen Kesehatan RI, 2008). Most CKD patients in Indonesia were undergoing hemodialysis therapy (99\%)[3]. HD is usually done for 3-5 hours, three times per week (Rocco, 2018).

Depression is commonly found in stage 5 CKD patients as a response to the initiation of dialysis therapy (Nissenson, 2017). Among stage 5 CKD patients, the prevalence of major depression is reported 29.1\% in Northern China (Liu, 2017), 43.6\% in Saudi Arabia (Othayq, 2020), 54.8\% in Korea (Koo, 2003), 72\% in Pakistan (Anees, 2018). A previous study in Indonesia using the BDI questionnaire reported that among HD patients, $23.7 \%$ experienced mild depression, $15.4 \%$ moderate depression, and $8.3 \%$ severe depression (Musthafa, 2020). However, depression in HD patients is usually neglected, underdiagnosed, and remains untreated (Daugirdas, 2015). Several factors can trigger depression in CKD patients undergoing HD, including disruption of activities and time constraints (De Sousa, 2008), job loss (Simanjuntak, 2017), marital status, education level, presence of sleep disturbances, and financial support (Kronik, 2011). HD duration is also reported to be significantly correlated with depression (Huda, 2021). Patients who have undergone HD for a long time tend to have lower levels of depression compared to respondents who have just

Copyright: (c) 2021 the Author(s). This article is an open access article distributed under the terms and conditions of the Creative Commons Attribution (CC-BY) 4.0 license (https://creativecommons.org/licenses/by/4.0/). Published by Al-Kindi Centre for Research and Development, London, United Kingdom. 
undergone HD because the longer a person has undergone HD, he will become more adaptive (Octafiani, 2020). They have dealt with various pressures and have developed strategies to be adaptive (Indrarini, 2019).

Previously, there were several similar studies with varying results and depression assessment tools. Therefore, this study aims to investigate the correlation between the duration of hemodialysis and depression in CKD patients so depression can be diagnosed and treated to reduce hospitalization rates and patient mortality.

\section{Methods}

A cross-sectional study was carried out from 30th August until 30th September 2021. 52 CKD patients undergoing HD at Dr. Soetomo General Academic Hospital were included using consecutive sampling for analysis. This study used the Beck Depression Inventories-II (BDI-II) to measure depression. The total score of the 21 questions on BDI-II was compared with depression scoring and classified into four categories. 0-13 classified as minimum depression, 14-19 as mild depression, 20-28 as moderate depression, and 29-63 as severe depression. The collected data were analyzed for data cleaning, coding, and tabulation. Data analysis was performed using IBM SPSS Statistics for Windows version 25.0. (IBM Corp., Armonk, NY, USA). The research used was univariate and bivariate. Univariate data is presented in a frequency distribution, while the bivariate analysis used in this study used the Pearson test. Data distribution was evaluated using a one-sample Kolmogorov-Smirnov test. Variables with a $p$-value $<0.05$ from the bivariate analysis were considered significant.

This study has obtained ethical clearance before data collection from Dr. Soetomo General Academic Hospital Research Ethical Board (Ethical approval number 0090/KEPK/XI/2020, approval date 2nd November 2020).

\section{Results}

\subsection{Characteristic of CKD Patients undergoing HD at RSUD Dr.Soetomo}

Among 52 HD patients, most of the respondents were in the age range of 51-60 years (51.7\%), with an average of 47.85 years. The sex ratio of men and women is the same (50\%). The detailed characteristics of the respondents can be seen in Table 1.

Table 1. Characteristic of CKD Patients undergoing HD at Dr. Soetomo General Academic Hospital

\begin{tabular}{lll}
\hline Characteristics & Total $(\mathbf{n = 5 2 )}$ & Percentage (\%) \\
\hline Age & & \\
$21-30$ & 3 & 5.8 \\
$31-40$ & 9 & 17.3 \\
$41-50$ & 13 & 25 \\
$51-60$ & 27 & 51.9 \\
Total & 52 & 100 \\
Average \pm SD & $47.85 \pm 9.396$ & \\
\hline Gender & & \\
Male & 26 & 50 \\
Female & 26 & 50 \\
Total & 52 & 100 \\
\hline
\end{tabular}

\subsection{Duration of Hemodialysis in CKD Patients undergoing HD}

The shortest duration of HD is six months, and the longest is 120 months, and most patients have undergone HD $37-48$ months (21.2\%). Further details about the duration of hemodialysis are presented in Table 2. 
Table 2. Duration of Hemodialysis in CKD Patients undergoing HD at Dr. Soetomo General Academic Hospital

\begin{tabular}{|c|c|c|}
\hline Duration of HD (months) & Total $(n=52)$ & Percentage (\%) \\
\hline $6-12$ & 7 & 13.5 \\
\hline $13-24$ & 9 & 17.3 \\
\hline $25-36$ & 7 & 13.4 \\
\hline $37-48$ & 11 & 21.2 \\
\hline $49-60$ & 4 & 7.7 \\
\hline $61-72$ & 3 & 5.8 \\
\hline $73-84$ & 7 & 13.4 \\
\hline $85-96$ & 0 & 0 \\
\hline $97-108$ & 0 & 0 \\
\hline $109-120$ & 4 & 7.7 \\
\hline Total & 52 & 100 \\
\hline Mean $\pm S D$ & \multicolumn{2}{|l|}{$48.17+31.6$} \\
\hline $\begin{array}{l}\text { of Depression in CKD Pat } \\
\text { re of CKD Patients underg }\end{array}$ & $\begin{array}{l}\text { ergoing HD } \\
\text { Dr. Soetomo } C\end{array}$ & mic Hospital \\
\hline BDI Score & Total $(n=52)$ & Percentage (\%) \\
\hline 0-13 (Minimal) & 45 & 86.5 \\
\hline 14-19 (Mild) & 5 & 9.6 \\
\hline 20-28 (Moderate) & 2 & 3.8 \\
\hline 29-63 (Severe) & 0 & 0 \\
\hline Total & 52 & 100 \\
\hline Mean + SD & $7.13+5.3$ & \\
\hline
\end{tabular}

3.3 Prevalence of Depression in CKD Patients undergoing HD

Table 3. BDI Score of CKD Patients undergoing HD at Dr. Soetomo General Academic Hospital

Our findings revealed that out of 52 participants, five patients (9.6\%) were classified into mild depression, two patients (3.8\%) were classified into moderate depression, and 45 patients (86.6\%) were classified into minimal depression. No patient was classified into major depression.

\subsection{Correlation Between Duration of Hemodialysis and Depression}

The Pearson test showed a significant negative correlation between the duration of hemodialysis and depression $(p=0.005, p>0.05$; $r=-0.094)$. This study revealed that mild depression (9.6\%) was mostly found in HD duration $\leq 36$ months, and moderate depression (3.8\%) was found in HD duration 6 months and 84 months. The cross-tabulation between the duration of depression was presented in Table 4. 
Table 4. Bivariate Analysis between Duration of HD and depression in CKD Patients Undergoing HD at Dr. Soetomo General Academic Hospital

\begin{tabular}{|c|c|c|c|c|c|c|c|c|c|c|}
\hline & & \multicolumn{6}{|c|}{ Depression } & & & \multirow{3}{*}{$\begin{array}{l}p \text {-value } \\
\text { and } r\end{array}$} \\
\hline & & \multicolumn{2}{|c|}{ Minimal } & \multicolumn{2}{|c|}{ Mild } & \multicolumn{2}{|c|}{ Moderate } & \multicolumn{2}{|c|}{ Total } & \\
\hline & & $\mathrm{n}$ & $\%$ & $\mathrm{n}$ & $\%$ & $\mathrm{n}$ & $\%$ & $\mathrm{~N}$ & $\%$ & \\
\hline \multirow{10}{*}{$\begin{array}{l}\text { Duration } \\
\text { of HD } \\
\text { (months) }\end{array}$} & $6-12$ & 5 & 9.6 & 1 & 1.9 & 1 & 1.9 & 7 & 13.4 & \multirow{11}{*}{$\begin{array}{l}p= \\
0.005 \\
r= \\
(-0.094)\end{array}$} \\
\hline & $13-24$ & 7 & 13.5 & 2 & 3.8 & 0 & 0 & 9 & 17.3 & \\
\hline & $25-36$ & 6 & 11.5 & 1 & 1.9 & 0 & 0 & 7 & 13.4 & \\
\hline & $37-48$ & 11 & 21.2 & 0 & 0 & 0 & 0 & 11 & 21.2 & \\
\hline & $49-60$ & 4 & 7.7 & 0 & 0 & 0 & 0 & 4 & 7.7 & \\
\hline & $61-72$ & 3 & 5.8 & 0 & 0 & 0 & 0 & 3 & 5.8 & \\
\hline & $73-84$ & 6 & 11.5 & 0 & 0 & 1 & 1.9 & 7 & 13.4 & \\
\hline & $85-96$ & 0 & 0 & 0 & 0 & 0 & 0 & 0 & 0 & \\
\hline & $97-108$ & 0 & 0 & 0 & 0 & 0 & 0 & 0 & 0 & \\
\hline & $108-120$ & 3 & 5.8 & 1 & 1.9 & 0 & 0 & 4 & 7.7 & \\
\hline Total & & 45 & 86.5 & 5 & 9.6 & 2 & 3.8 & 52 & 100 & \\
\hline
\end{tabular}

\section{Discussion}

This study showed that, on average, patients underwent HD for 48.17 months. The shortest duration of HD is six months, while the longest is 120 months. Most patients were undergoing HD for 37-48 months (21.2\%). This result was in line with the previous study that reported that most respondents (32.9\%) experienced HD for $\geq 36$ months (Indrarini, 2019). In addition, Korin et al. showed that the duration of HD was varied, ranging from 3 months to 168 months (14 years) (Korin, 2020). As a result of starting dialysis therapy, depression is common in stage 5 CKD patients. Several factors can trigger depression in CKD patients undergoing HD, including disruption of activities and time constraints, job loss (De Sousa, 2018), marital status, education level, presence of sleep disturbances, and financial support (Wu, 2004). Our study showed that out of 52 participants, five patients (9.6\%) had mild depression, two patients (3.8\%) had moderate depression, and 45 patients (86.6\%) had minimal depression. However, no patient was classified into major depression.

Our analysis revealed a significant correlation between the duration of HD and depression $(p=0.005, p>0.05)$. Pearson correlation value of -0.094 indicates a negative correlation which means the longer the duration of HD, the lower the depression score. Our result was in line with previous findings in Indonesia, which showed a negative correlation between the duration of HD and depression means that the longer a person has undergone HD, the lower score of depression.

Ashari et al. revealed that patients who have recently undergone HD have depression levels that vary from no depression, mild depression, moderate depression, to even severe depression. In contrast, only mild depression was found in patients who have been on HD for a long time. Additionally, a study also reported that most major depression (50\%) occurred in patients who had just undergone hemodialysis for $<6$ months, while $91.7 \%$ of respondents who did not experience depression have undergone HD $>12$ months. In CKD patients undergoing HD < 12 months, a total of 20 (39.2\%) patients had experienced mild depression, and 5 (9.8\%) had experienced moderate depression (Octafiani, 2020). This situation most likely was caused by adapting to HD therapy, which they have to accept and require a large amount of money (Armiyati, 2014). Following previous studies, this study revealed that mild depression (9.6\%) and moderate depression (3.8\%) were found in the lower HD duration. Anees et al. reported the duration of dialysis was from 3 to 49 months with a mean of $19.64 \pm 11.7$ months, and most patients (56.1\%) were moderate to severely depressed. Compared to that result, our study showed a lower number of depression, most likely because we had a higher mean of HD duration.

There are several factors that influence the level of depression in CKD patients, including coping mechanisms [17]. Compared to respondents who have just undergone HD, patients who have had longer HD duration tend to have lower levels of depression because the longer they have undergone HD, the more adaptable they are. They have dealt with various pressures and have developed strategies to be adaptive. According to $\mathrm{Wu}$. A et al. CKD patients who had undergone HD for more than one year showed improvements in various physical, mental, and sexual aspects compared to those who had undergone HD for less than one year. 
Family support was also significantly associated with depression in HD patients, which can help to lower the risk of depression in these individuals. A study reported that patients who have undergone HD > 12 months have adapted and depended on family support. Based on a previous study which was conducted on HD patients at Dr. Soetomo General Academic Hospital, 34.6 percent of patients had high family support, 63.4 percent had sufficient family support, and $2 \%$ had less family support. Sufficient family support in this study meant that the family could accept and share all of the patient's conditions, that they were committed to accompanying the patient until they felt the patient's problems, and were responsible for patient care (Wijayanti, 2028). KublerRoss, E. \& Kessler, D.'s theory stated that there are five stages in the face of grief: denial, anger, bargaining, depression, and acceptance. The low depression score in the majority of patients who had long HD duration is most likely caused by they are already in the stages of acceptance or acceptance.

In contrast, a study reported no correlation between the duration of hemodialysis and depression. It was most likely caused by the interview process, which was not optimal. Many patients stopped the interview process temporarily, intervention from the family when the patient answered interview questions, and the lack of consent of patients and families to be interviewed.

\section{Conclusion}

Based on the result presented, it was concluded that there was a significant negative correlation between the duration of hemodialysis and depression in CKD patients. The longer duration of hemodialysis, the lower score of depression in CKD patients.

This study still has limitations. This study cannot control several factors that influence depression scores, such as family support, coping mechanisms, job loss, marital status, education level, presence of sleep disturbances, and financial support. Our findings suggested that further research about factors correlated with depression in HD patients is needed. Periodic evaluation of HD patients is also required to give early intervention. Thus, the morbidity of CKD patients undergoing HD due to depression can be reduced.

\section{References}

[1] National Kidney Foundation. (2002). Clinical practice guidelines for chronic kidney disease: evaluation, classification and stratification. National Kidney Foundation.

[2] Hill NR, Fatoba ST, Oke JL, Hirst JA, O'Callaghan CA, Lasserson DS (2016). The global prevalence of chronic kidney disease - A systematic review and meta-analysis. PLoS ONE 11. https://doi.org/10.1371/journal.pone.0158765.

[3] Indonesian Renal Registry. (2018). $11^{\text {th }}$ Report Of Indonesian Renal Registry. Retrieved: May 10, 2020, from https://www.indonesianrenalregistry.- org/data/IRR\%202018.pdf

[4] Departemen Kesehatan RI, Direktorat Bina Pelayanan Medik Spesialistik, dan Direktorat Jenderal Bina Pelayanan Medik. (2008). Pedoman Pelayanan Hemodialisis di Sarana Pelayanan Kesehatan. Jakarta: Departemen Kesehatan RI.

[5] Rocco M, Daugirdas JT, Depner TA, Inrig J, Mehrotra R, Rocco M. (2015). KDOQI Clinical Practice Guideline for Hemodialysis Adequacy: 2015 Update. American Journal of Kidney Diseases; 66:884-930. https://doi.org/10.1053/j.ajkd.2015.07.015.

[6] Nissenson AR, Fine RN. (2017). Handbook of Dialysis Therapy: $5^{\text {th }}$ Edition. Philadelphia: Elsevier Health Sciences.

[7] Liu X, Yang X, Yao L, Zhang Q, Sun D, Zhu X. (2017). Prevalence and related factors of depressive symptoms in hemodialysis patients in northern China. BMC Psychiatry; 17. https://doi.org/10.1186/s12888-017-1294-2.

[8] Othayq A, Aqeeli A. (2020). Prevalence of depression and associated factors among hemodialyzed patients in Jazan area, Saudi Arabia: a cross-sectional study. Mental Illness 2020;12:1-5. https://doi.org/10.1108/MIJ-02-2020-0004.

[9] Koo J.R, Yoon J.W, Kim S.G, Lee Y.K, Oh K.H, Kim G.H, (2003). Association of Depression With Malnutrition in Chronic Hemodialysis Patients.

[10] Anees M, Barki H, Masood M, Ibrahim M, Mumtaz A. (2018). Depression in Hemodialysis Patients. Vol. 24.

[11] Musthafa S, Armelia L. (2020). Angka Kejadian Depresi Pada Pasien Hemodialisis Menggunakan Metode Pengukuran Back Depression Inventory. Majalah Kesehatan Pharmamedika;11. https://doi.org/10.33476/mkp.v11i2.1325.

[12] Daugirdas JT, Blake PG, Ing TS. (2015). Handbook of dialysis $5^{\text {th }}$ edition. US: Lippincott Williams \& Wilkins.

[13] De Sousa A. (2008). Psychiatric issues in renal failure and dialysis. Indian journal of nephrology. Apr;18(2):47.

[14] Simanjuntak VO, Lamtiar RR, Sitepu JN. (2017). Korelasi Lama Menjalani Hemodialisis Dengan Skor Depresi Pada Pasien Gagal Ginjal Kronik Yang Menjalani Hemodialisis Di Instalasi Dialisis RSUD Dr. Pirngadi Medan Periode Januari-Maret Tahun. Pirngadi Medan Periode JanuariMaret Tahun:63-8.

[15] Kronik G, Ungaran DR, Ashari NA, Aini F, Purwaningsih H, Program M (2011). Hubungan Lama Menjalani Hemodialisa Dengan Tingkat Depresi Pada Pasien Gagal Ginjal Kronik di RSUD Ungaran.

[16] Korin JM, Nugrahayu EY, Devianto N. (2020). Hubungan Lama Menjalani Hemodialisis dengan Tingkat Depresi pada Pasien Hemodialisis di RSUD Abdul Wahab Sjahranie Samarinda. Jurnal Sains dan Kesehatan. Dec 31;2(4):367-72.

[17] Huda Al Husna C, Ika Nur Rohmah A, Ayu Pramesti A, Muhammadiyah Malang U, Jl Bendungan Sutami No I, Lowokwaru K, (2021). Hubungan Lama Menjalani Hemodialisis dengan Kecemasan Pasien. Indonesian Journal of Nursing Health Science ISSN;6:31-8.

[18] Octafiani M, Armelia L. (2020). Angka Kejadian Depresi pada Pasien yang Menjalani Hemodialisis Menggunakan Metode Pengukuran Geriatric Depression Scale. Majalah Kesehatan Pharmamedika;12(1).

[19] Armiyati Y, Rahayu DA. (2014). Faktor yang berkorelasi terhadap mekanisme koping pasien ckd yang menjalani hemodialisis di rsud kota semarang (Correlating factors of coping mechanism on CKD patients undergoing Hemodialysis in RSUD Kota Semarang). Inprosiding seminar nasional \& internasional. 
[20] Indrarini A, Zahra AN, Yona S. (2019). The relationship between anemia, depression, duration of hemodialysis, and quality of sleep among end-stage renal disease patients. Enfermeria Clinica;29:24-9. https://doi.org/10.1016/j.enfcli.2019.05.002.

[21] Wu AW, Fink NE, Marsh-Manzi JVR, Meyer KB, Finkelstein FO, Chapman MM (2004). Changes in Quality of Life during Hemodialysis and Peritoneal Dialysis Treatment: Generic and Disease-Specific Measures. Journal of the American Society of Nephrology 2004;15:743-53. https://doi.org/10.1097/01.ASN.0000113315.81448.CA.

[22] Baeti NN, Maryati H. (2016). The Relation Of Family's Support With The Level Of Depression For Patient Who Gets Hemodialysis In The Room Of Hemodialysis At Hospital Of Jombang District. Jurnal Ilmiah Keperawatan (Scientific Journal of Nursing). Mar 1;2(1):66-71.

[23] Wijayanti D, Dinarwiyata D, Tumini T. (2018). Self Care Management Pasien Hemodialisa Ditinjau Dari Dukungan Keluarga Di Rsud Dr. Soetomo Surabaya. Jurnal Ilmu Kesehatan. 4;6(2):109-17.

[24] Sompie EM, Kaunang TM, Munayang H. (2015). Hubungan antara lama menjalani hemodialisis dengan depresi pada pasien dengan penyakit ginjal kronik di rsup. prof. dr. rd kandou manado. e-CliniC. Feb 11;3(1). 